\title{
Evaluation of Smoke Free Area Policy in Enrekang Regency
}

\author{
Nawir Rahman ${ }^{1}$, Risma Niswaty ${ }^{2}$, Afridha Noor Pewara \\ ${ }^{1}$ Departement of Economic Education, Postgraduate Program, STKIP Pembangunan Indonesia \\ (email: nawir.rahman05@gmail com) \\ ${ }^{2}$ Universitas Negeri Makassar
}

\begin{abstract}
Public policy evaluation is a process of activities that are planned to assess the overall effectiveness of the program and it is deemed necessary to make changes to policies that have been carried out in order to achieve objectives. The objectives of this study are (i) How is the performance of the smoke-free area policy in Bone-bone village, Baraka sub-district, Enrekang district? (ii) What is the determinant factor in implementing the smoke-free area policy in Bone-bone village, Baraka sub-district, Enrekang district? This type of research is a descriptive study with a qualitative research design. Data collection techniques are carried out through observation, interviews and documentation. The data analysis technique used consists of data condensation, data presentation and drawing conclusions. The results of this study indicate that (i) the performance of the smoke-free area policy in Bone-bone village, Baraka subdistrict, Enrekang district is quite effective, judged by the policy evaluation indicators by William N Dunn including effectiveness, efficiency, adequacy, leveling, responsiveness, and leveling. (ii) the determinant factors of the application of smoke-free areas, namely the existence of a leader or agent, a religious community, and the existence of sanctions.
\end{abstract}

\section{Keywords:}

evaluation; policy; smoke-free areas

\section{Introduction}

The development of a nation can be seen from the progress of a region. The health aspect is one of the indicators of its success, because without health the implementation of comprehensive national development will not materialize. Indonesia is the country with the third highest number of smokers in the world after China and India. Based on the 2018 Basic Health Research (Riskesdas) data, the prevalence of smokers over the age of 15 reached 33.8\% and the population aged 10-18 years increased from $7.2 \%$ in 2013 to $9.1 \%$ in 2018 . Government efforts to formulate various regulations and policies that can be implemented in overcoming the effects of the dangers of smoking include, through Law Number 36 of 2009 concerning Health. Article 115 paragraph 2 states that local governments are obliged to establish smoking-free areas in their areas. Smoking-free areas (KTR) are spaces or areas that are 
declared prohibited from carrying out smoking activities, producing, selling, advertising, promoting and or promoting tobacco products (n.d.)

The impact of smoking on public health and the environment was followed up by the regional government of the province of South Sulawesi by issuing Governor Regulation Number 1 of 2015 concerning No Smoking Areas (n.d.) and continued by Regional Regulation of Enrekang Regency Number 2 of 2009 concerning Regional Health Systems (n.d.)

Bone-bone Village, Baraka District, Enrekang Regency is one of the villages that implements a smoke-free area policy. The background to the idea of a smoke-free village program originated from the concerns of the village head who was then held by Muhammad Idris, who discovered the fact that $70 \%$ of its residents were smokers before the implementation of the smoke-free area regulations. Not only by adults but also by children aged 6-12 years. There is a main objective, namely for development, at first the village head, Pak Idris, examines the problem of smoking from an economic, health and educational perspective.

Seeing this concern, Bone-bone Village Regulation No. 1 of 2009 concerning NonSmoking Areas, in which a policy issued by the Bone-bone village government prohibits Bonebone villagers and people from other areas to smoke, sell, and advertise cigarette / tobacco products in the Bone-bone village area, (n.d.)

As is well known, this Bone-bone village regulation applies not only to Bone-bone villagers, but also to immigrant guests. However, the facts that are found today are that there are still a handful of people, both Bone-bone villagers and immigrant guests, who deviate from this. Various reasons emerged when asked for information, namely they did not know about the prohibition of smoking (newcomers), then the smoking habit was difficult to get rid of, and also because the temperature in Bone-bone Village was quite cold, thus provoking their desire to smoke to warm their bodies. even though the village government has imposed sanctions on community members who violate the regulations. This is evident from reports of several Bone-bone villagers who found newcomers who smoked.

From the explanation described above, evaluation is needed to determine the extent of the success rate of the smoke-free zone policy. Where in evaluating a policy it is necessary to look at the problems that arise in its application and then linked and measured with indicators of policy success. According to Winarno (2005), the term policy may be used 
broadly as in "Indonesian foreign policy", "Japanese economic policy", and / or it may also be used to become something more specific.

Thomas R. Dye in (Winarno, 2016, p. 19), "public policy is whatever the government chooses to do and not do". Dye's limits may be considered rather precise, but they are still insufficient to make a clear distinction between what the government decides to do and what the government actually does. As for Wibawa (Andi Cudai Nur et al., 2020, p. 84), policy implementation is the embodiment of decisions regarding fundamental policies, usually contained in a law, but can also take the form of important executive instructions or legislative decisions.

The public policy process can be more easily understood if it is examined step by step. This is what makes public policy "colorful" and its studies so dynamic. Speaking of the public policy process Dunn (2003, p. 25) describes the public policy stages of formulation; problem; forecasting; recommendation; monitoring; and evaluation.

Dunn explains the stages of public policy from problem formulation, forecasting, recommendations, monitoring and evaluation.

1) Problem Formulation. Problem formulation can supply policy-relevant knowledge that questions the assumptions underlying the problem definition and enters the policymaking process through agenda setting. Problem formulation can help uncover hidden assumptions, diagnose causes, map possible goals, combine conflicting views and design new opportunities.

2) Forecasting. Forecasting can provide policy-relevant knowledge about problems that will occur in the future as a result of taking alternatives, including not doing something. This is done in the policy formulation stage. Forecasting can test the plausible, potential, and normatively valuable future, estimate the consequences of existing or proposed policies, identify possible constraints that will occur in achieving goals, and estimate the public feasibility (support and disposition) of various options.

3) Recommendations. Recommendations generate policy-relevant knowledge about the benefits or costs of various alternatives whose future consequences have been estimated through forecasting. This helps policy makers at the policy adoption stage. Recommendations help estimate the level of risk and uncertainty, identify externalities and multiple effects, 
determine criteria for making choices, and determine administrative responsibility for policy implementation.

4) Monitoring Monitoring provides policy-relevant knowledge about the consequences of previously taken policies. This helps policy makers at the policy implementation stage. Monitoring helps assess the level of compliance, find unintended consequences of policies and programmes, identify impediments and impediments to implementation, and locate the responsible parties at each stage of the policy.

5) Evaluation. The evaluation produces policy-relevant knowledge about the discrepancy between the expected policy performance and what is actually produced. So this helps policy making at the policy assessment stage of the policy making process.

Public Policy broadly includes the stages of policy problem formulation, policy implementation and policy evaluation. The process of making public policy is a complex process because it involves many stages and variables that must be studied. Some political experts who are interested in studying public policy divide the processes of public policy making into several stages.

Policy implementation is basically how the government works or the process carried out by the government to make policies produce the planned conditions. Van Meter and Van Horn in (Mulyadi, 2016, p. 47) stated that policy implementation is an action taken by the government and private sector, both individually and in groups intended to achieve goals. It can be concluded that policy implementation is a process carried out by actors so that policies get results in accordance with the objectives and plans.

Policy evaluation is an activity that involves an estimate or an assessment. Evaluation is seen as a functional activity. This means that evaluation is not only carried out at the final stage but for the entire process of program activities. Nawawi ( 2009, p. 155), states that "evaluation is an activity to assess or see the success or failure of an organization or work unit in carrying out the tasks and functions assigned to it". Evaluation is carried out in order to ascertain the achievement of results, progress and obstacles encountered in implementing the strategic plan which can be assessed and studied to become a reference for future improvements. In his study of social theory, Boyle in (Malwa, 2019, p. 47). 
A public policy cannot be removed just like that. Policies need to be monitored, and one such monitoring mechanism is the "Cultural evaluation". A. Cudai Nur, et al (2020, p. 105), argue that evaluation is the final stage of a policy process, and if it is deemed necessary, changes to the policies that have been made can be made. The main purpose of the evaluation is not to blame but to see how big the gap is between the achievements and expectations of a public policy. Evaluation aims to find shortcomings and then cover up the shortcomings.

Specifically, Dunn (2003) developed three approaches to evaluating policy implementation, namely pseudo evaluation, formal evaluation, and theoretical decision evaluation. For more details, it will be described as follows, pseudo evaluation; Formal evaluation; Decision theoretic evaluation. Overall policy implementation is evaluated by measuring program output based on policy objectives. The output of the program is seen through its impact on the intended targets, both individuals and groups as well as the community. The output of policy implementation is change and acceptance of change by both target groups and non-target groups, Akib in (Simatupang and Akib, 2011).

Preparation of the policy implementation process so that a policy can achieve the desired goals must utilize existing resources, involve people or groups of people in implementation, interpret policies, programs implemented must be planned with good management, and provide services and benefits to the community. Regarding the factors that influence the implementation of a program's policy, G. Shabbir Cheema and Dennis A. Rondinelli in (Subarsono, 2008, p. 101) argue that there are factors that influence the implementation of decentralized government program policies. These factors are:

1) Environmental conditions. The environment greatly influences the implementation of policies, which means this environment includes the socio-cultural environment as well as the involvement of program recipients.

2) Relationships between organizations. In many programs, the implementation of a program requires support and coordination with other agencies. For this reason, inter-agency coordination and cooperation is needed for the success of a program

3) Organizational resources. For program implementation Policy implementation needs to be supported by both human resources and non-human resources.

4) Characteristics and abilities of implementing agents What is meant by the characteristics and abilities of implementing agents are the bureaucratic structures, 
norms, and patterns of relationships that occur in the bureaucracy, all of which will affect the implementation of a program.

Meanwhile, according to James Anderson in (Suntoro, 2015, p. 79), there are several factors that influence policy implementation, namely:

1) There is a concept of selective non-compliance with the law, where there are several laws and regulations or public policies that are less binding on individuals.

2) Because community members are in a group or association where they have ideas or thoughts that are not in accordance with or contrary to legal regulations and the wishes of the government.

3) There is a desire to seek profit quickly, including members of the community who tend to act by cheating or by violating the law.

4) There is legal uncertainty or unclear "size" of policies that may conflict with each other, which can be a source of people's non-compliance with laws or public policies.

5) If a policy is sharply opposed (contrary) to the value system adopted by the wider community or certain groups in society.

To be able to judge whether a public policy is successful or not in its implementation, there are experts who express their opinions from different points of view. In this case, to produce information on policy implementation, several different indicators are used to evaluate the implementation of the policy. According to Dunn in (Hariyanto, 2017, pp. 52 54), there are six criteria that can be used to assess a successful or unsuccessful performance, namely: 1) effectiveness, 2) efficiency, 3) adequacy, 4) smoothness, 5) responsiveness , and 6) accuracy. So researchers use Dunn's policy evaluation theory because Dunn's theory is more relevant to research to be carried out by researchers, namely the indicators or evaluation criteria that include these six indicators.

\section{Methods}

The research method used is descriptive using a qualitative approach that prioritizes the depth of data, then assesses and interprets it. The location of this research is located in Bone-bone village, Baraka sub-district, Enrekang district. Sources of data in this study include 
primary and secondary data sources. The data collection instruments in this study were observation, interviews, and documentation. The informants in this study include, namely the Head of Bone-bone Village, influential community leaders in the Bone-bone village, health workers, youth leaders, cigarette sellers, and housewives. The data analysis technique used in this research is the qualitative analysis used by researchers as suggested by Milles Huberman \& Saldana (2014, pp 31-33) namely Data Condensation, Data Presentation, Conclusion Drawing and Verification.

\section{Results and Discussion}

Evaluation of the Non-Smoking Area Policy in Bone-bone village, Baraka sub-district, Enrekang district. Policy making, of course, to achieve certain goals, it is not uncommon for environmental factors to make the goals to be achieved not in line with expectations. Evaluation then becomes indispensable to assess the performance of a policy. Policy evaluation has an important role in providing feedback on what is happening in a program/practice/technology related to a policy.

Boyle in (Malwa, 2019, p. 47) argues that evaluation is carried out to be able to ascertain the achievement of results, progress and obstacles encountered in implementing the strategic plan that can be assessed and studied to become a reference for future improvements. Policy evaluation is an activity related to estimation or an assessment. Evaluation is assessed as a functional activity, meaning that evaluation is not only carried out at the final stage but also for the entire process of program activities.

\section{1) Effectiveness}

Campbell J.P in (Saragih, 2017) explains that the measurement of the effectiveness of a policy can be seen by the success of targets, where the measurement of effectiveness is viewed from the point of view of achieving goals, where the success of an organization must consider not only organizational goals but also the mechanism for maintaining goals. In the research results, the KTR policy had a positive impact on health, economic, and education aspects for the Bone-bone community.

Atmawikarta (2009) argues, at a macro level a population with a good health level is an important input for reducing poverty, economic growth and long-term economic development. On the health aspect, Village Regulation Number 1 of 2009 concerning 
Smoking-Free Areas has a positive impact on health conditions in which people with ARI from year to year have decreased:

\section{Table 1.}

Levels of Patients with Ispa in Bone-bone Village

\begin{tabular}{cccccccccccccc}
\hline Year & Ja & Fe & Mar & Apr & Mei & Jun & Jul & Agu & Sep & Okt & Nov & Des & Tot \\
\hline $\mathbf{2 0 1 1}$ & 7 & 7 & 4 & 5 & 7 & 3 & 2 & 15 & 0 & 1 & 16 & 6 & 73 \\
$\mathbf{2 0 1 2}$ & 2 & 2 & 15 & 5 & 1 & 0 & 3 & 2 & 1 & 14 & 21 & - & 66 \\
$\mathbf{2 0 1 3}$ & 12 & 3 & 5 & 1 & 0 & 6 & 8 & 8 & 11 & 7 & 7 & - & 68 \\
$\mathbf{2 0 1 4}$ & - & - & 3 & - & 8 & 3 & 6 & 2 & 9 & 2 & 1 & 5 & 36 \\
$\mathbf{2 0 1 5}$ & - & - & 3 & - & - & - & - & - & - & - & - & - & 3 \\
$\mathbf{2 0 1 6}$ & - & 1 & - & 2 & - & - & - & - & - & - & - & - & 3 \\
$\mathbf{2 0 1 7}$ & - & 1 & - & - & - & 2 & - & - & - & - & - & - & 3 \\
$\mathbf{2 0 1 8}$ & - & 1 & - & - & - & - & - & - & - & - & - & - & 1 \\
$\mathbf{2 0 1 9}$ & - & - & - & - & - & - & - & - & - & - & - & - & 0 \\
$\mathbf{2 0 2 0}$ & - & - & - & - & - & - & - & - & - & - & - & - & 0 \\
\hline
\end{tabular}

Source: Village Health Post (POSKESDES) Bone-bone 2011-2020

The table above can be explained that people suffering from ARI from 2011-2020 experienced a decline. Most patients with ARI suffered in 2011 as many as 73 people and experienced a drastic decline entering 2015 and until 2020 there were no residents who were recorded as having ISPA.

Economic Aspects, the economy basically influences the education and development of an area. Prathama and Mandala in (Iskarno et al., 2014) emphasize that without economic growth, there will be no increase in welfare, productivity and income distribution in a country.

Bone-bone community thinks smoking is harmful. Both in terms of health and economy. The economic condition of the Bone-bone village community before the smoke-free area was implemented can be said to be mediocre. The smoke-free zone policy has a good impact on most of the economic conditions of the community. Especially housewives who have a better understanding of the financial condition of their family really feel the benefits after their family members stop smoking. For them, the daily necessities of life and the costs for children's education are sufficient. Likewise for cigarette sellers, who argued that selling cigarettes in Bone-bone village did not bring any profit because most residents chose to go into debt and it took a long time for them to return their capital. Until now, many people have built houses, renovated houses, and also owned vehicles after leaving the smoking habit. 
From the aspect of education, education has a major influence on the development of an area. According to (Harsono, 2011) education is the process of changing the attitudes and procedures of a person or group of people in an effort to mature humans through teaching and training efforts.

The smoke-free area policy brought a good change for the people of Bone-bone village, where before the implementation of the smoking ban, many children smoked at an early age and eventually dropped out of school. After implementing a smoke-free area, the condition of education in Bone-bone village has increased from year to year to the level of education from 2009-2020. The number of people completing college is increasing. Currently there are no children who are not in school for reasons of cost. Parents are more able to pay for their children's education so that it triggers the children's enthusiasm to go to school, of course, with more decent clothes. even many of them go to school to a higher level.

From the health aspect, health is an indispensable human capital in supporting economic development. This is because health supports increasing work productivity. The people of Bone-bone village are starting to feel the impact. Where before the implementation of the smoke-free area, many people complained because of shortness of breath, easily tired in activities, coughing, and Respiratory Tract Infections (ARI). Both from the parents to the baby. This is caused because people who smoke not only harm themselves but also others who are exposed to cigarette smoke. This is evident from the data obtained from the Bonebone POSKESDES.

The following is a table of educational conditions in Bone-bone village:

Table 2.

\section{Education Level in Bone-bone Village}

\begin{tabular}{cccccc}
\hline Year & Pre-school & Elementary & $\begin{array}{c}\text { Junior High } \\
\text { School }\end{array}$ & $\begin{array}{c}\text { Senior High } \\
\text { School }\end{array}$ & $\begin{array}{c}\text { Diploma/ } \\
\text { Graduate }\end{array}$ \\
\hline 2009 & 158 & 107 & 235 & 269 & 16 \\
2010 & 165 & 110 & 232 & 274 & 21 \\
2011 & 158 & 102 & 246 & 286 & 25 \\
2012 & 166 & 105 & 216 & 310 & 28 \\
2013 & 160 & 98 & 245 & 303 & 29 \\
2014 & 164 & 95 & 220 & 338 & 32 \\
2015 & 160 & 91 & 237 & 332 & 38 \\
2016 & 155 & 82 & 247 & 344 & 38 \\
2017 & 148 & 65 & 268 & 355 & 39 \\
2018 & 142 & 67 & 272 & 369 & 40 \\
\hline
\end{tabular}




\begin{tabular}{llllll}
\hline 2019 & 152 & 65 & 277 & 370 & 41 \\
2020 & 149 & 60 & 292 & 381 & 43 \\
\hline
\end{tabular}

Source: Bone-bone village office, 2009-2020

In the economic aspect, the economic condition of the people of Bone-bone village before the implementation of a smoke-free area can be said to be mediocre. With a livelihood as a farmer who does not have a fixed income. If it is added to the habit of smoking which drains the family's expenses, the daily necessities of life and the children's school fees will stagnate. Because every expenditure to buy cigarettes can be up to forty thousand to fifty thousand per day, and if multiplied in a period of one week, month, even per year, the expenditure will be very clear. In addition, cigarettes indirectly greatly affect the economic condition of rural communities, this can be seen from the income or performance of people who tend to be weak or less at work when they are still smoking, compared to when they have stopped and stay away from smoking.

The policy of a smoke-free area has a good impact on most people's economic conditions. In particular, housewives who are more aware of their family's financial condition really feel the benefits after their family members stop smoking. For them, their daily needs and the cost of their children's education are fulfilled. Likewise for cigarette sellers, who think that selling cigarettes in Bone-bone village does not bring any profit because most people choose to borrow and it takes a long time for them to get their capital back. Until now, many people have built houses, renovated houses, and also vehicles after quitting smoking.

\section{2) Efficiency}

Efficiency refers to how much effort is needed to produce a level of effectiveness. The efforts made by the village government are to conduct socialization and supervision. The form of socialization carried out by the Bone-bone village government consists of two, namely direct socialization and indirect socialization.

Socialization according to (Herdiana, 2018) is a process that is carried out after a policy is made and carried out before the policy enters the implementation stage. Direct socialization was carried out by the Bone-bone village government by holding counseling regarding the impact of smoking which was carried out face-to-face, namely holding meetings at the mosque. The socialization carried out by the village government does not immediately prohibit smoking, but is carried out in stages. Initially, the community was only prohibited from smoking in public places, then it was continued by prohibiting smoking in public places 
and inside the house. then the village government then prohibited the community from selling cigarettes in the Bone-bone area. Seeing a change in community behavior, the village government banned smoking in the entire Bone-bone village area. The second is indirect socialization, carried out by the government by using printed media such as the installation of posters, banners, or bulletin boards in public places. However, the implementation of socialization and counseling has rarely been carried out.

This form of supervision is carried out directly by the village pack together with village officials, and also involves local residents to immediately report if they see residents smoking in public places, either Bone-bone villagers or immigrants. Then to supervise residents who still smoke in the house, the village pack supervises by involving children and housewives.

The current socialization is much different when the new rules for the prohibition of smoking are implemented are rarely carried out. Socialization is usually done often, now it is only done twice to remind residents not to ignore the applicable rules. The reason is that the smoking ban has become a village regulation and there are sanctions for violations. The following is a picture of the condition of the warning board and the no smoking poster:

\section{Figure 1.}

\section{Posters and warning boards for smoke-free areas}
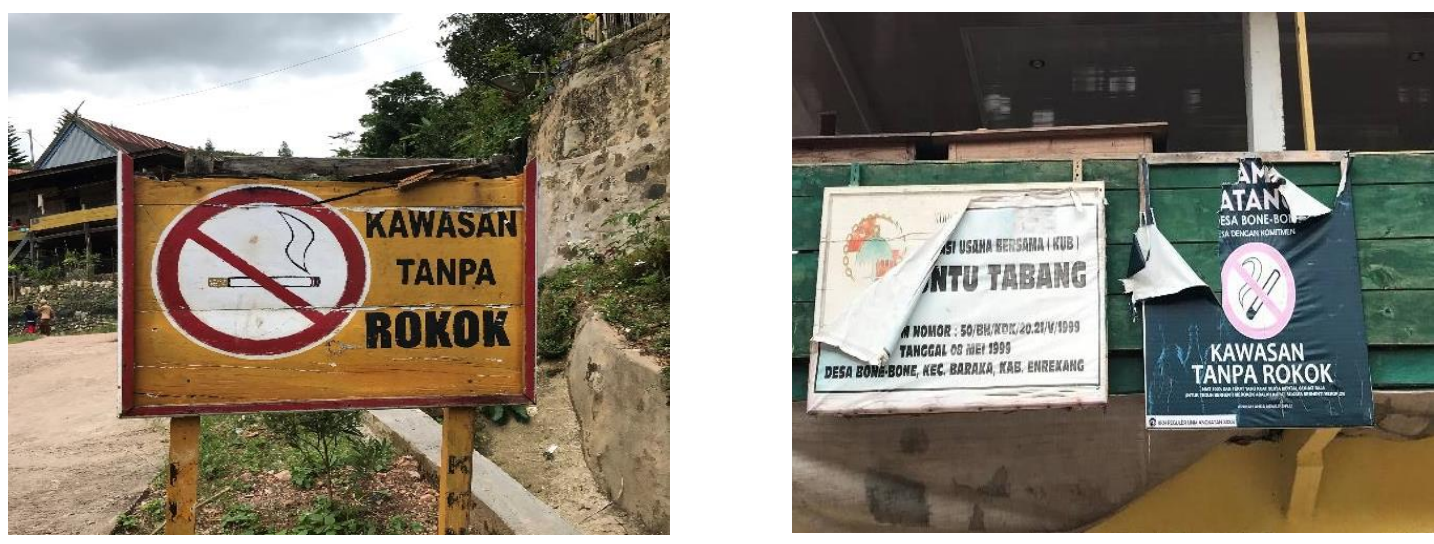

\section{3) Adequacy}

Adequacy is based on seeing how far the results that have been achieved can solve a problem or problem by implementing a smoke-free area policy in Bone-bone village. whether the policy is able to reduce the number of smokers in Bone-bone village.

From the results of the study, the cigarette smoke area policy that applies in Bone-bone village can be concluded that it is able to reduce the number of smokers. The reduction in the number of smokers was assessed from the fact that no residents were seen smoking in public 
places and also no cigarette butts were found along the Bone-bone area. Although there are still some young people who smoke, they have never been seen in public.

Likewise, when attending a crowd event held in Bone-bone village such as mutual cooperation, weddings, or other crowds, no one can be seen holding, or smoking a cigarette. As stated by Idris as the head of Bone-bone village, although there are still some residents who still smoke in secret ways such as in their homes or in gardens, it can be ascertained that 90\% more of the male residents in Bone-bone village have quit. smoke.

In order to maintain the behavior of residents who have quit smoking a lot from year to year, the village government strives to prevent smoking behavior of its residents from an early age. Parents are encouraged to send their children to Islamic schools after completing elementary school.

Bone-bone residents think smoking is haram or illegal. The religious understanding that is still very strong in the village of Bone-bone is the reason many residents stop smoking. parents try to educate children from an early age so as not to do things that harm themselves or others, including smoking. Most of the children in Bone-bone village are currently studying in pesantren. This was corrected by the children who were interviewed and chose to continue their education at the pesantren after graduating from elementary school.

\section{4) Equity}

Equity is the distribution of benefits evenly to different groups of people, Dunn (Hariyanto, 2017). The leveling here is intended to see the application of the sanctions that have been regulated in Bone-bone village regulation number 1 of 2009 concerning smoke-free areas. Whether the sanctions that have been regulated are appropriate and applied to any citizen or guest who violates the rules of the smoke-free zone.

Sanctions according to (Rudy T, 2009, p. 152) are the threat of punishment, a means of coercion in order to be obeyed by a rule, a law such as sanctions against violators of a law. The purpose of imposing sanctions on those who violate the law is to provide a deterrent effect on violators from repeating their mistakes again, as well as for guidelines / instructions in carrying out something without breaking the law.

From the research results, the application of sanctions has been carried out properly. Social sanctions such as cleaning public facilities, namely mosques, schools, fields, and others. The sanction given in Bone-bone village is also not indiscriminate. Sanctions apply to anyone 
who violates, even if the violator is an official. So that it can open people's minds that even officials will be subject to sanctions if they violate, especially ordinary people. The choice of social sanctions related to the violation of smoke-free areas by the village head and community leaders is still considered ineffective to cause a deterrent effect for some communities. This is evident because there are still a handful of people who smoke secretly in their gardens.

\section{5) Responsiveness}

As stated by Hassel Nogi S. Tangklissan (2005, p. 177) responsiveness is the ability of the bureaucracy to recognize community needs, arrange service priority agendas, and develop service programs according to community needs and aspirations.

The application of Village Regulation Number 1 of 2009 concerning Smoking-Free Areas aims to minimize and assist people to stay away from cigarettes or stop smoking. However, it is undeniable that most people in Bone-bone village, especially smokers, object to the implementation of the smoke-free zone policy. They assume that smoking is something that is personal that they are free to do.

Responding to community criticism and complaints, the village government gave a firm response to residents who criticized the smoke-free zone policy and linked smoking with everyone's human rights. The village government then responded with the same answer that breathing clean air is also a right for everyone. Likewise for cigarette sellers who complain because they feel disadvantaged, Pak Idris as the village head invites the cigarette sellers to discuss the issue of profit and loss from selling cigarettes, that in fact they are losing selling cigarettes.

Departing from this explanation, the authors can conclude that the impact of the smoke-free zone policy provides satisfaction for the community. People who support more than people who disagree.

\section{6) Appropriateness/Accuracy}

The accuracy with respect to the results achieved during the implementation of the smoke-free zone policy has been right on target, Dunn (Hariyanto, 2017). In other words, can the smoke-free area policy in Bone-bone village be equally beneficial and beneficial to all Bone-bone village communities where aspects of the community are the target of the policy or only benefit certain groups of society. 
The policy regarding smoke-free areas by the Bone-bone village government has the principle that $100 \%$ of the Bone-bone village area becomes a smoke-free area. What is meant is to provide protection from the dangers of cigarette smoke for all residents of Bone-bone Village, provide a clean and healthy space and environment for the community, protect public health in general from the adverse effects of smoking both directly and indirectly and also create and inherit a clean environment. and healthy, free from cigarette smoke to the next generation.

To create a smoke-free area is not easy. Moreover, to create a smoke-free area in a village consisting of three hamlets with a population of more than 800 people. However, the persistence and enthusiasm of Mr. Idris as the head of Bone-bone village succeeded in making the smoking ban become a village regulation.

The author can conclude that the smoke-free area policy in Bone-bone village provides benefits, namely: (i) It has a positive impact on health, family economy, and education for Bone-bone villagers (ii) Residents feel the benefits for their bodies. quitting smoking can affect a person's stamina when doing daily activities especially strenuous activities. (iii) Residents can breathe fresher and cooler air without having to fear being exposed to cigarette smoke. Not only Bone-bone villagers who feel the fresh air, but also immigrants. (iv) smoke-free zone policy brings existence to Bone-bone village. Currently Bone-bone village is widely known both from the district level and even to the center thanks to the regulation on smoking prohibition which has become a village regulation.

In addition to bringing benefits to the residents of Bone-bone village, the policy of a smoke-free area is expected to be useful for people outside Bone-bone so that this policy can also be applied in other places. The policy of a smoke-free area brings existence to the village of Bone-bone. Currently, Bone-bone village is well-known both from the district level and even to the center thanks to the smoking ban which has become a village regulation

\section{Determinant Factors in the Application of Smoke-Free Area Policy in Bone-Bone Village, Baraka District, Enrekang Regency}

1) Leader or Agent

According to Griffin and Pareek in (Wibowo, 2006, p. 118) that agents of change are professionals whose job is to help the community or group plan development or reshape 
goals, focus on problems, seek possible solutions, organize assistance, plan actions, what is meant. to improve situations, resolve difficulties, and evaluate the results of planned efforts.

His leadership is favored by the people of Bone-Bone. By gaining the trust of the community, Idris is reminded of his idea when he was still in college to change people's smoking behavior. Idris' closeness to the community, made Idris the first step to immediately implement his plan in changing the smoking behavior of the community with the assumption that the public likes him more. And it was proven that Idris succeeded in making Bone-bone village the first smoke-free area in Enrekang Regency in 2009.

\section{2) Religious Society}

In general, Bone-bone people are obedient to worship, since childhood they have been accustomed to going to the mosque to carry out congregational prayers. Bone-bone community who are educated from an early age about understanding religion and respect for parents, thus forming moral and polite behavior. Parents are encouraged to send their children to Islamic schools after completing elementary school. Religious community, make it easier for the local government to convince the Bone-bone community that smoking is haram. The view from the perspective of Islam that cigarettes are considered makruh and some say haram is one of the reasons that became the basis for the formation of the smoking ban in Bone-Bone village.

\section{3) There are sanctions}

In social change strategies, individual modification assumes that humans act on the basis of rewards and punishments. This strategy is carried out by providing predetermined rewards to individuals who are not willing to change their behavior (Martono, 2011, p. 253).

One of the efforts made by the Bone-Bone village government to make people stop smoking is by providing sanctions in the form of social sanctions. The existence of sanctions is considered to give the impression of regret to the perpetrator who violates the rules. Social sanctions are intended to provide a clear effect on society for the violations committed. Sanctions like this clearly have a psychological effect on the perpetrators of violations and become an example for other people not to make the same mistakes because of the consequences if they violate the rules that have been set. 


\section{Conclusion}

Based on the research results, it can be concluded that: (i) the performance of the Smoke-Free Area Policy regulated in Bone-bone Village Regulation Number 1 of 2009 is quite effective. This can be seen from the evaluation indicators, namely a) Effectiveness, the KTR policy has a positive impact on the aspects of health, economy, and education, for the Bonebone community, b) Efficiency, overall the efforts made by the government are quite efficient in changing the smoking behavior of the Bone community. -bone. However, for the past few years the village government has rarely provided counseling and was careless in monitoring, c) Adequacy, the existence of a smoke-free area has been able to reduce the number of smokers in Bone-bone village, d) Distribution, the application of sanctions has been carried out according to the rules in village regulations and applies to anyone who breaks. e) Responsiveness, the impact of the smoke-free area policy gives satisfaction to the Bone-bone village community. This is because most people in Bone-bone think that breathing clean air is a right for everyone. f) Accuracy, the establishment of a smoke-free zone policy is considered to be right on target, because considerable benefits are felt directly by the Bone-bone community, be it for health, family economy, and education. (ii) The determinants of the smoke-free zone policy implementation, namely a) Leaders or agents, b) Religious communities, c) The existence of sanctions.

\section{References}

Andi Cudai Nur, Risma Niswati, A. A. (2020). Kemitraan, Digitalisasi E Inovasi Kebijakan Publik di Era Globalisasi. Badan Penerbit UNM.

Atmawikarta, A. (2009). Investasi Kesehatan Untuk Pembangunan Ekonomi. Jakarta: BAPPENAS.

Dunn, Wi. N. (2003). Pengantar Analisis Kebijakan Publik. Yogyakarta: GADJAH MADA UNIVERSITY PRESS. GADJAH MADA UNIVERSITY PRESS.

Hariyanto, E. (2017). Efektivitas Penerbitan Sukuk Negara Sebagai Instrumen Pembiayaan APBN. Indonesian Treasury Review: Jurnal Perbendaharaan, Keuangan Negara Dan Kebijakan Publik, 2(1), 79-98.

Harsono, M. S. (2011). Etnografi Pendidikan sebagai desain penelitian kualitatif. Universitas Muhammadiyah Surakarta. 
Herdiana, D. (2018). Sosialisasi Kebijakan Publik: Pengertian dan Konsep Dasar. Jurnal Ilmiah Wawasan Insan Akademik, 1(3), 13-26.

Iskarno, P. E., Kuncara, H., \& Irianto, D. (2014). PENGARUH TINGKAT PENDIDIKAN DAN INFRASTRUKTUR TERHADAP PERTUMBUHAN EKONOMI DI INDONESIA (TAHUN 2008 â€“2012). Jurnal Pendidikan Ekonomi Dan Bisnis (JPEB), 2(1).

Malwa, R. U. (2019). Evaluasi Pelaksanaan Undang-Undang Nomor 5 Tahun 2014 tentang Aparatur Sipil Negara (ASN)(Studi Kasus: Pasal 22 tentang Hak PPPK) di Kantor Satuan Polisi Pamong Praja. Jurnal Pemerintahan Dan Politik, 4(2).

Martono, N. (2011). Sosiologi Perubahan Sosial: Perspektif Klasik, Modern, Posmodern, dan Poskolonial. PT Raja Grafindo Persada.

Mulyadi, D. (2016). Studi Kebijakan Publik dan Pelayanan Publik. Alfabeta.

Nawawi, I. (2009). Public Policy analisis, strategi advokasi teori dan praktek. Putra Media Nusantara (PMN).

Peratuaran Gubernur Nomor 1 tahun 2015. (n.d.). Tentang Kawasan Tanpa Rokok.

Peraturan Daerah Kabupaten Enrekang Nomor 2 Tahun 2009. (n.d.). Tentang Sistem Kesehatan Daerah.

Peraturan Desa Bone-Bone No. 1 Tahun 2009. (n.d.). Tentang Kawasan Bebas Asasp Rokok.

Rudy T, E. (dkk). (2009). Kamus Hukum. Sinar Grafika.

Saldana, J. et al. (2014). Qualitative Data Analysis A method Sourcebook. Arizona State University. Saragih, R. (2017). Efektivitas Kebijakan Penatausahaan Barang Milik Negara di Sekolah Tinggi Penyuluhan Pertanian Medan. Jurnal Administrasi Publik: Public Administration Journal, 7(1), 77-93.

Simatupang, P., \& Akib, H. (2011). Efektivitas Implementasi dan Dampak Kebijakan dalam Konteks Desentralisasi Pemerintahan. Jurnal Ilmiah Ilmu Administrasi Publik, 2(1), 1-9. Tangkilisan, H. N. S. (2005). Manajemen Publik. Grasindo.

Undang-Undang Nomor 36 Tahun 2009. (n.d.). Tentang Kesehatan.

Wibowo. (2006). Manajemen Perubahan. PT. Raja Grafindo Persada.

Winarno, B. (2005). Teori dan Proses Kebijakan Publik. media press.

Winarno, B. (2016). Kebijakan Publik Era Globalisasi Teori, Proses, dan Studi Kasus Komparatif. CAPS (Center of Academic Publishing Service). 